\title{
Impact of estradiol cypionate prior to TAI and progesterone supplementation at initial diestrus on ovarian and fertility responses in beef cows
}

\author{
T. Martins ${ }^{\text {a, }}$ J.P. Talamoni ${ }^{\text {b }}$, M. Sponchiado ${ }^{\text {a }}$, J.R.G. Maio ${ }^{\text {c }}$, G.P. Nogueira ${ }^{\text {d }}$, G. Pugliesi ${ }^{\text {a }}$, \\ M. Binelli ${ }^{a, *}$ \\ a Department of Animal Reproduction, School of Veterinary Medicine and Animal Science, University of São Paulo, Pirassununga, São Paulo, Brazil \\ ${ }^{\mathrm{b}}$ Department of Animal Reproduction, School of Veterinary Medicine, Camilo Castelo Branco University, Descalvado, São Paulo, Brazil \\ c Ouro Fino Saúde Animal, Ribeirão Preto, São Paulo, Brazil \\ 'Department of Support, Production and Animal Health, School of Veterinary Medicine of Araçatuba, São Paulo State University "Julio de Mesquita Filho", \\ Araçatuba, São Paulo, Brazil
}

\section{A R T I C L E I N F O}

\section{Article history:}

Received 12 April 2017

Received in revised form

11 August 2017

Accepted 14 August 2017

Available online 19 August 2017

\section{Keywords:}

Beef cattle

Proestrus

Luteolysis

Pregnancy

Follicle

\begin{abstract}
A B S T R A C T
In cattle, early diestrus progesterone (P4) supplementation modulates endometrial function to exert proand anti-pregnancy establishment effects; specifically, P4 stimulates conceptus growth, but also induces early onset of luteolysis. This paradoxical effect is frequently related to the inconsistent fertility outcomes that result from P4 supplementation experiments. Aim was to investigate the impact of exogenous estradiol (E2) treatment at the end of timed fixed AI (TAI) on frequency of early luteolysis and pregnancy of beef cows supplemented with P4. Ovulations (D0 of study) of suckled multiparous ( $\mathrm{n}=643$ ) and primiparous ( $\mathrm{n}=193$ ) Nelore cows (Bos indicus) were synchronized with an E2/P4-based protocol for TAI and assigned to receive $1.0 \mathrm{mg}$ of estradiol cypionate (CP) or nothing (NoCP) on D-2 and $150 \mathrm{mg}$ of injectable long-acting P4 (iP4) or Placebo (NoiP4) on D4 on a $2 \times 2$ factorial arrangement. On D15, the iP4 supplementation increased $(\mathrm{P}<0.05)$ the frequency of early luteolysis $(\mathrm{NoCP}+\mathrm{iP4}: 26.0 \%$; $[13 / 50]$ vs. NoCP: $8.0 \%$ [4/50]), but CP prevented this effect (CP + iP4: 8.3\% [4/48] and CP: $6.4 \%$ [3/47]). The CP improved pregnancy/AI (P/AI) of multiparous (CP: 51.6\% [165/320] and NoCP: 35.0\% [113/323]; P < 0.001) and primiparous cows (CP: 40.4\% [40/99] and NoCP: 24.5\% [23/94], P < 0.05), regardless of iP4 treatment. The iP4 supplementation affected P/AI of CP and NoCP treated cows according to follicle size at TAI. For the $\mathrm{CP}$ treated cows, the iP4 supplementation improved P/AI of sub-populations of cows with follicles $<12.35 \mathrm{~mm}$ (42.0\% [34/81] vs. 53.1\% [34/64]), while for NoCP treated cows, the improvements occurred in subpopulations of cows with follicles $\geq 12.35 \mathrm{~mm}$ ( $46.1 \%$ [35/76] vs. $58.7 \%$ [37/63]). In conclusion, strategies associating E2 and P4 supplementation decrease the incidence of early onset of luteolysis and improve P/AI of suckled beef cows with smaller follicles.
\end{abstract}

๑) 2017 Elsevier Inc. All rights reserved.

\section{Introduction}

In addition to genetic gains, timed artificial insemination (TAI) programs in beef cattle improves reproductive efficiency because it overcomes challenges associated to long anestrous periods and estrus detection, that delay the time to first service post-partum. Despite of such benefits, cows induced to ovulate dominant follicles smaller than $11.0 \mathrm{~mm}$ at TAI present low pregnancy per AI (P/

\footnotetext{
* Corresponding author

E-mail address: binelli@usp.br (M. Binelli).
}

AI) $[1-3]$. Such poor results are mainly attributable to the insufficient uterine exposure to estradiol (E2) and progesterone (P4) at the pre-ovulatory (proestrus/estrus) and post-ovulatory (diestrus) periods [4,5], respectively. Indeed, aiming to achieve an adequate sequential uterine exposure to E2 and P4, different strategies to stimulate follicle growth in beef cattle submitted to TAI were proposed [6,7]. For example, consistent fertility gains in TAI protocol have been achieved by extending the proestrus period [8,9] or adding exogenous E2 [5,10,11]. An adequate uterine exposure to E2 affects positively the fertilization process [12], reduces the incidence of early luteolysis [13,14], and provides an uterine 
environment favourable to the establishment of pregnancy $[15,16]$. Regarding P4 concentrations during diestrus, the relationship between P4 concentrations and fertility are generally positive $[3,6,17]$. Progesterone is critical for successful maternal recognition and maintenance of pregnancy $[18,19]$. This steroid stimulates endometrial secretions [20] associated with conceptus growth [21-23] and interferon- $\tau$ production [24,25]. Therefore, manipulation of the endocrine environment by the addition of exogenous E2 and/or P4 can potentially improve fertility outcomes in TAI programs.

Forde et al. [23] demonstrated that insertion of an intravaginal p4-releasing device between days 3 and 7 after estrus advanced expression of endometrial genes related to energy provision and histotroph constituents. Such alterations seems to be associated with greater conceptuses growth during late diestrus, that was also observed by others using a similar approaches [22,23]. Commonly, the benefits of $\mathrm{P} 4$ supplementation on fertility are observed when administration occur at early diestrus (i.e., days 3-7 after ovulation) $[26,27]$. However, in many studies, P4 supplementation at this period causes a greater incidence (30-35\%) of early luteolysis (i.e., by day 14), that may impair maternal recognition and maintenance of pregnancy $[24,28]$. This paradoxical effect is one of the main explanations for the inconsistent fertility results obtained in response to different strategies to supplement $\mathrm{P} 4$ at early diestrus. Indeed, studies reported no effect [29-31], a negative effect [29,32,33], or a positive effect [34-36] of P4 supplementation on P/ AI of beef and dairy cattle.

One plausible explanation for the incidence of early luteolysis in P4-supplemented cows is that the early increase in circulating P4 is related to advances in the timing of nuclear P4 receptor (PGR) downregulation in the endometrial epithelia [37]. The downregulation of the PGR is closely followed by an increase in epithelial estrogen receptor alpha (ER $\alpha$ ) and oxytocin receptors (OXTR), resulting in the pulsatile release of PGF2 $\alpha$, which induces luteolysis $[38,39]$. Furthermore, inconsistent fertility results can be a consequence of differences in the timing, duration, source and dose of P4 treatments [26,27].

Recently, a long-acting injectable P4 formulation (iP4) was evaluated by Pugliesi et al. [40] to supplement P4 at early diestrus in a manner that would be more practical than the use of the P4 intravaginal device or multiple P4 injections. By a single administration of 150 or $300 \mathrm{mg}$ iP4 on days 2 or 3 post-ovulation, the authors observed that supplementation efficiently increased the circulating P4 concentrations for $\geq 3$ days during early luteal phase in non-suckled Nelore cows, but also increased the frequency of early luteolysis (0\% vs. 40.7\%). Despite of this apparent negative aspect, in a subsequent fertility trial using an E2/P4-based TAI protocol, Pugliesi et al. [35] verified that $150 \mathrm{mg}$ of iP4 administered 4 days post TAI ( $\sim 3$ days post-ovulation) increased the P/AI of anestrous suckled beef cows by $20 \%$. Thus, our recent findings highlight the somewhat paradoxical effects of $\mathrm{P} 4$ supplementation when given in the early diestrus, as shown previously by others [24]; there are both beneficial effects regarding uterine receptivity and conceptus elongation and potentially negative effects associated with reduced $\mathrm{CL}$ lifespan. Thus, it is critical to find strategies to minimize the negative, while emphasizing the beneficial effects of P4 supplementation to maximize efficiency of this technology. Here, we propose to test the effects of supplementing E2 concurrent with the withdrawal of the P4-releasing device (i.e., at the beginning of proestrus) as a strategy to support the beneficial effects of exogenous P4 administration to improve fertility in beef cattle.

The exposure of the endometrium to the rising proestrus concentrations of E2 stimulates ER $\alpha$ and PGR [41,42], and this is indirectly responsible for the decrease of OXTR during metaestrus and early diestrus [13]. Thus, it is possible that E2 supplementation could cause a greater increase of ER $\alpha$ and PGR than the endogenous E2 pre-ovulatory surge. A greater initial rise in PGR could compensate the advanced disappearance of PGR caused by P4 supplementation. This represents a possible alternative to bypass the detrimental aspects of P4 supplementation. In fact, there is evidence for a positive role of proestrus E2 alone on uterine [15] and luteal $[8,13,15]$ functions during diestrus, establishment of pregnancy $[5,43,44]$ and fertility $[5,10,11]$. However, the associated response to supplemental E2 and P4 is unknown. Therefore, in this study, we aimed to evaluate the role of E2 supplementation at the P4 device withdrawal on the incidence of advanced luteolysis and fertility outcome after iP4 supplementation at early diestrus. Specifically, we tested the hypothesis that the E2 supplementation (1) decreased the incidence of short luteal lifespan and (2) improved the fertility response obtained by diestrus iP4 supplementation.

\section{Materials and methods}

\subsection{Animals}

This experiment was carried out during the summer and early fall on a commercial beef operation located in Mato Grosso do Sul, Brazil. Suckled multiparous $(n=643)$ and primiparous $(n=193)$ Nellore cows used in this study exhibited an average of days of postpartum of 52.1 and 50.8 (range, 31 to 85) and body condition scores of 3.48 and 3.00 (BCS, range, 2.25 to $5.00 ; 1=$ emaciated to $5=$ obese [45], using 0.25 increments), respectively. The cows were kept in grazing conditions (Brachiaria brizantha) with ad libitum access to water and minerals. The multiparous cows were split into 5 and 2 allotments from farms $1(\mathrm{n}=524)$ and $2(\mathrm{n}=119)$, respectively, while the primiparous cows were split into 4 allotments on farm 1.

All animal procedures were approved by the Ethics and Animal Handling Committee of the School of Veterinary Medicine and Animal Science of the University of Sao Paulo under the protocol number CEUA-6236220316.

\subsection{Experimental design}

Within each allotment, cows were subjected to an estrus synchronization protocol based on a single administration of $2 \mathrm{mg}$ of estradiol benzoate $\left(2.0 \mathrm{~mL}\right.$, i.m., Sincrodiol ${ }^{\circledR}$ Ourofino Saúde Ani$\mathrm{mal}$ ) and insertion of an intravaginal P4-releasing device (1.0 g, Sincrogest ${ }^{\circledR}$ Ourofino Saúde Animal) followed by visual evaluation of BCS, on day -10 . On this day, a transrectal ultrasonography exam was performed to exclude any cows with abnormalities of the reproductive tract and to establish the ovarian status. The ovarian status was determined based in three predefined categories, presence of $\mathrm{CL}$, absence of $\mathrm{CL}$ and presence of follicles $<8.0 \mathrm{~mm}$ and absence of $\mathrm{CL}$ and presence of follicles $\geq 8.0 \mathrm{~mm}$.

On day -2, P4 devices were removed, and cows received $0.53 \mathrm{mg}$ of sodium cloprostenol $\left(2.0 \mathrm{~mL}\right.$, i.m., Sincrocio ${ }^{\circledR}$ Ourofino Saúde Animal) followed by administration of 300 IU of equine chorionic gonadotropin $\left(1.5 \mathrm{~mL}\right.$, i.m., SincroeCG ${ }^{\circledR}$ Ourofino Saúde Animal). At the time of device removal, Estrotect ${ }^{\mathrm{TM}}$ patches (Western Point Inc., Apple Valley, MN) were applied halfway between the hip and tail head to determine the occurrence of mounting behavior associated with estrus. Concurrent with TAI (day 0 ), all cows received $10 \mu \mathrm{g}$ of gonadotropin releasing hormone analogue (buserelin acetate, $2.5 \mathrm{~mL}$, i.m., Sincroforte ${ }^{\circledR}$ Ourofino Saúde Animal).

Cows were blocked based on the BCS (low: L-BCS, 2.00 to 2.50, moderate: M-BCS, 2.75 to 3.50 or high: H-BCS, 3.75 to 5.00$)$ to receive one of four treatments: injection of $1.0 \mathrm{mg}$ of estradiol cypionate (CP, $1.0 \mathrm{~mL}$, i.m, SincroCP ${ }^{\circledR}$ Ourofino Saúde Animal) or 
none (NoCP) on day -2 and supplementation with $150 \mathrm{mg}$ of longacting P4 (iP4, $1.0 \mathrm{~mL}$, i.m., Sincrogest ${ }^{\circledR}$ injectable Ourofino Saúde Animal) or placebo (NoiP4, Sincrogest ${ }^{\circledR}$ injectable vehicle) on day 4 , on a 2 by 2 factorial arrangement of treatments $(\mathrm{CP}, \mathrm{CP}+\mathrm{iP} 4$, NoCP and NoCP + iP4). Administration of $\mathrm{CP}$ at the time of P4 device withdrawal was based on previous publications [46,47]. Compared to estradiol benzoate, CP releases estradiol more slowly. Thus, it may be injected earlier in the protocol, at the same moment as the P4-releasing device withdrawal. This is advantageous for management because it reduces one handling of the animals and allows easy supplementation of estradiol.

On the day of TAI (day 0 ), cows were assigned randomly within treatments to receive a single insemination by one of four experienced operators using frozen-thawed commercial semen from 12 and three sires on farm 1 and farm 2, respectively. At the time of TAI, the cows with approximately $50 \%$ or more of the silver rub-off coating removed from the Estrotect device were considered to have been in estrus between days -2 and 0 .

\subsection{Ultrasound examinations}

Ultrasonography exams were performed in B-mode with a 7.5 $\mathrm{MHz}$ linear-array transrectal transducer by the same operator on days $-10,0$ and 4 .

On day 0 , the diameter of the largest ovarian follicle observed in the B-mode still image was determined by taking the average between measurements of its two perpendicular axes. These measurements were taken only in cows with follicles $\geq 6.5 \mathrm{~mm}(\mathrm{n}=561$ and $n=154$ for multiparous and primiparous cows, respectively). On day 4 , the ovaries were evaluated for detection of a newly formed CL, and its maximum area was determined by B-mode still image and the tracing function. For CL with an anechoic fluid-filled cavity, the area of the cavity was subtracted from the total area [48]. For primiparous cows, the evaluations on day 4 were performed in only 94 out of 193 animals due to operational constraints.

For determining early onset of luteolysis after P4 supplementation, a subgroup of ovulated multiparous cows $(n=195)$ were evaluated by Colour Doppler ultrasonography on day 15 . The CL scanning was performed using an ultrasound equipped with pulsewave colour Doppler function and a multi-frequency linear transducer. The evaluation and proportion of colour signals of luteal blood flow were performed and determined as described previously in cattle [49]. A scale from 0 to $100 \%$ with $5 \%$ interval points was used for visually determining the proportion of the luteal area with blood flow signals. All scans were performed at a constant colour-gain setting and a velocity setting of $5.4 \mathrm{~cm} / \mathrm{s}$ by an operator unaware of the treatment allocation of animals. The criteria for describing a cow that underwent early structural luteolysis were: (1) the presence of a CL area $<2.0 \mathrm{~cm}^{2}$ and (2) CL blood flow signals that covered $\leq 25 \%$ of the total luteal area on day 15 , as reported previously $[34,40,49]$.

Pregnancy diagnosis was conducted by transrectal ultrasonography 30-35 days after TAI. Conception rate was calculated as the proportion of ovulated cows (i.e. with CL on day 4) that became pregnant due to TAI, and P/AI was calculated as the proportion of total cows inseminated that were pregnant.

\subsection{Blood sampling for analysis of serum $\mathrm{P}_{4}$ concentrations}

Blood sampling for determination of circulating concentrations of P4 was taken from the subgroup of cows that were submitted to ovarian ultrasonography on day $15(\mathrm{n}=195)$. The serum P4 concentrations were used for identification of functional luteolysis, defined as $\mathrm{P} 4$ concentrations $<1.0 \mathrm{ng} / \mathrm{mL}$ [40]. Blood samples were collected from coccygeal vessels, centrifuged at $1500 \mathrm{~g}$ for $10 \mathrm{~min}$ at room temperature; serum was stored at $-20{ }^{\circ} \mathrm{C}$ until hormonal assays were performed.

Serum P4 was assayed by solid-phase radioimmunoassay using an Immuchem ${ }^{\mathrm{TM}}$ Double Antibody Progesterone Kit (Cat. 07-170105, MP Biomedicals, NY, USA) according to manufacturer's instructions. The detection limit (sensibility) of the assay was $0.1 \mathrm{ng} / \mathrm{mL}$. The intra-assay coefficients of variation (CV), were $0.17 \%$ (low) and $7.39 \%$ (high), respectively. The inter-assay CVs were $14.48 \%$ (low) and $9.95 \%$ (high), respectively.

\subsection{Statistical analyses}

All statistical analyses were carried out using SAS (version 9.3, SAS Institute Inc., Cary, NC, USA). Cows were the experimental units in all models. The analyses of datasets containing primiparous and multiparous cows were ran separately.

For continuous dependent variables (follicle diameter, CL area, and $\mathrm{P} 4$ concentrations), the assumptions of normality of residues and homogeneity of variance were checked by histograms, q-q plots, and formal statistical tests as part of GLM and the UNIVARIATE procedure of SAS. The natural logarithmic transformation and square root were respectively used to normalize the data distribution of the $\mathrm{CL}$ area and P4 concentrations. Non-transformed data were shown for clarity. These variables were analyzed by ANOVA using the MIXED procedure of SAS. Follicle diameter on day 0 and $\mathrm{CL}$ area on day 4 were measured before P4 supplementation. For these variables, only the effect of $\mathrm{CP}$ was included into the model as a fixed effect. Area of the CL on day 15 was analyzed according to the fixed effects of $\mathrm{CP}$, iP4 supplementation and their interaction. On additional analyses, the variable estrous behavior and the appropriate interactions were included as fixed effects into the model, but only for multiparous cows, due the limited number of primiparous cows detected in estrus.

Binomial, dependent variables were analyzed by the GLIMMIX procedure of SAS, using binomial distribution. For rates of ovulation and estrus, only the fixed effect of $\mathrm{CP}$ it was included in the model. For rates of conception and pregnancy, the fixed effect of CP, iP4 supplementation and their interaction were included in the model. For primiparous cows, the conception rate analysis was not performed because the ovulation was checked only in a limited number of animals on day $4(\mathrm{n}=94)$. For further analyses of pregnancy, the variables estrous behavior (only for multiparous) or ovarian status at day -10 (i.e., presence or absence of $\mathrm{CL}$ ), and the appropriate interactions were included as fixed effects in the model.

For continuous and binomial dependent variables, the effects of BCS block, farm, and allotment nested within farm were included as random effects in the model. For primiparous cows, the farm effect was not included because they belonged to a single farm. To determine the denominator degrees of freedom for tests of fixed effect, the options Kenward-Roger and Between-Within degrees was used into the models of continuous and binomial dependent variables, respectively.

To evaluate the effect of follicle diameter (day 0 ) and CL area (day 4) on pregnancy rate in the model described previously, each variable was manually included as a covariate, and the appropriate interactions were considered. According to the covariate effects, the GLM procedure of SAS was used to establish whether the effect was linear, quadratic, or cubic. The significant, more complex model was selected. Then, the logistical regression models were designed using the intercept and slope value generated by the LOGISTIC DESC procedure of SAS for the following equation: Probability = $\left(\mathrm{e}^{\text {logisticequation }}\right) /\left(1+{ }^{\text {elogistic equation }}\right)$. Subsequently, the same analysis was conducted, but each continuous variable was divided in two classes according to the median $(<\mathrm{m}$ or $\geq \mathrm{m}$ ) to be included as fixed 
effects in the models. None of these latter analyses were performed for primiparous cows due the limited number of animals.

The effects of treatments were determined by F-tests using Type III sums of squares. When necessary, means across treatments were compared using Fisher's protected least significant difference (LSD, i.e., the DIFF option of the LSMEANS statement). Results of continuous variables were reported as LSMEANS \pm S.E.M and from binomial variables as means. A probability of $\mathrm{P} \leq 0.05$ indicated that a difference was significant, and a probability of $0.05>\mathrm{P} \leq 0.10$ indicated that significance was approached.

The proportion of the luteal area containing blood flow signals was analyzed using the non-parametrical Kruskal-Wallis test of the NPAR1WAY procedure of SAS. The comparisons of frequency of luteolysis between treatments were performed with the FREQ procedure using the Chi-squared distribution of SAS.

\section{Results}

Effects of supplementation of CP prior to TAI and iP4 at initial diestrus on fertility of suckled beef cows.

An effect of CP treatment on the conception rate was detected for multiparous cows (CP: 59.1\% [165/279] vs. NoCP: 41.2\% [113/ 274]; $\mathrm{P}<0.001$, Table 1 ). The $\mathrm{P} / \mathrm{AI}$ was also influenced positively by CP treatment both in multiparous (CP: 51.6\% [165/320] vs. NoCP: 35.0\% [113/323]; $\mathrm{P}<0.001$ ) and primiparous (CP: 40.4\% [40/99] vs. NoCP: $24.5 \%$ [23/94]; $\mathrm{P}=0.03)$ cows. There was no main effect of iP4 nor a CP by iP4 interaction (P $>0.10$; Table 1$)$.
The CP increased the proportion of cows showing estrus at TAI (Table 2), and this was associated positively with P/AI. In fact, multiparous cows detected in estrus presented greater $(\mathrm{P}<0.001)$ conception (67.4\% [145/215] vs. 39.3\% [133/338]) and P/AI (65.0\% [145/223] vs. 31.2\% [133/420]), regardless of treatment. Multiparous cows in estrus presented larger follicle diameters at TAI (Estrus: $13.55 \pm 0.29$ vs. Noestrus: $11.62 \pm 0.27 \mathrm{~mm}$; P $<0.001$ ), regardless of treatment.

There was an interaction $(\mathrm{P}=0.04)$ between the covariate follicle diameter at TAI and the variables CP and iP4 on pregnancy rate of multiparous cows. The relationship that better explained the effect of this covariate on pregnancy rate according to treatment was linear for NoCP and NoCP + iP4 treatments and quadratic for $\mathrm{CP}$ and $\mathrm{CP}+\mathrm{iP} 4$ treatments (Fig. 1). The iP4 supplementation appears to improve probability of pregnancy when follicle diameters were greater in cows not treated with $\mathrm{CP}$ (NoCP $+\mathrm{iP} 4$ group), while for cows treated with $\mathrm{CP}(\mathrm{CP}+\mathrm{iP} 4$ group $)$ the apparent positive effect occurred when cows presented smaller follicle diameter.

For clarity, when follicles were categorized according to the median $(12.35 \mathrm{~mm})$ in the classes $<12.35$ and $\geq 12.35 \mathrm{~mm}$, the treatment by follicle size interaction approached significance $(P=0.06$; Fig. 2). For follicles that were $\geq 12.35 \mathrm{~mm}$, the mean group comparisons demonstrated that pregnancy rate of $\mathrm{NoCP}+\mathrm{iP4}$ group was intermediate between the NoCP and CP groups. This indicated an increase in fertility promoted by iP4 supplementation, compatible with the observations of results from Fig. 1 for this group. For each group, the comparisons between

Table 1

Effect of CP supplementation 2 days prior to TAI and/or iP4 supplementation 4 days post-TAI on fertility of suckled beef cows.

\begin{tabular}{|c|c|c|c|c|c|c|c|}
\hline \multirow[t]{2}{*}{ Variables/Category } & \multicolumn{2}{|l|}{$\mathrm{CP}$} & \multicolumn{2}{|l|}{ NoCP } & \multicolumn{3}{|l|}{ P value } \\
\hline & NoiP4 & iP4 & NoiP4 & iP4 & $\overline{\mathrm{CP}}$ & iP4 & $\mathrm{CP} * \mathrm{iP} 4$ \\
\hline \multicolumn{8}{|l|}{ Multiparous } \\
\hline Conception/AI,\% (n/n) & $\begin{array}{l}60.1 \\
(83 / 138)\end{array}$ & $\begin{array}{l}58.2 \\
(82 / 141)\end{array}$ & $\begin{array}{l}38.3 \\
(54 / 141)\end{array}$ & $\begin{array}{l}44.4 \\
(59 / 133)\end{array}$ & $<0.001$ & 0.62 & 0.36 \\
\hline $\mathrm{P} / \mathrm{AI}, \%(\mathrm{n} / \mathrm{n})^{\mathrm{b}}$ & $\begin{array}{l}51.2 \\
(83 / 162)\end{array}$ & $\begin{array}{l}51.9 \\
(82 / 158)\end{array}$ & $\begin{array}{l}32.9 \\
(54 / 164)\end{array}$ & $\begin{array}{l}37.1 \\
(59 / 159)\end{array}$ & $<0.001$ & 0.51 & 0.65 \\
\hline \multicolumn{8}{|l|}{ Primiparous $^{\mathrm{C}}$} \\
\hline $\mathrm{P} / \mathrm{AI}, \%(\mathrm{n} / \mathrm{n})^{\mathrm{b}}$ & $\begin{array}{l}48.0 \\
(24 / 50)\end{array}$ & $\begin{array}{l}32.7 \\
(16 / 49)\end{array}$ & $\begin{array}{l}25.5 \\
(12 / 47)\end{array}$ & $\begin{array}{l}23.4 \\
(11 / 47)\end{array}$ & 0.03 & 0.23 & 0.41 \\
\hline
\end{tabular}

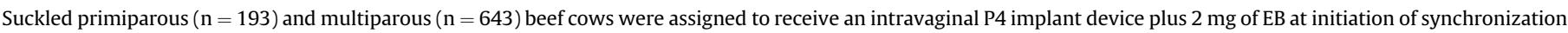

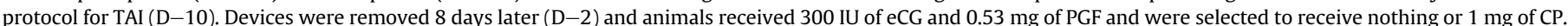

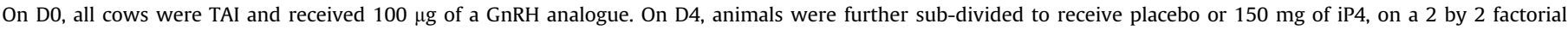
arrangement of treatments. Pregnancy diagnosis was performed by transrectal ultrasonography between days 30 and 35 .

a Conception/AI = number of pregnant cows divided by the number of cows detected with a CL 4 days after TAI.

b $\mathrm{P} / \mathrm{AI}=$ number of pregnant cows divided by the total number of cows that received TAI.

c Conception analysis was not performed for primiparous because ovulation was checked only in a sub-sample of animals on D4 ( $\mathrm{n}=94$ ).

Table 2

Effect of CP supplementation prior TAI on ovarian characteristics and estrus behavior.

\begin{tabular}{|c|c|c|c|c|c|c|}
\hline \multirow[t]{2}{*}{ Variables } & \multicolumn{2}{|l|}{ Multiparous } & \multirow[t]{2}{*}{$P$ value } & \multicolumn{2}{|l|}{ Primiparous } & \multirow[t]{2}{*}{ P value } \\
\hline & $\mathrm{CP}$ & $\mathrm{NoCP}$ & & $\mathrm{CP}$ & $\mathrm{NoCP}$ & \\
\hline $\mathrm{FD}$ on $\mathrm{D} 0(\mathrm{~mm})$ & $12.32 \pm 0.33$ & $12.37 \pm 0.33$ & 0.83 & $11.06 \pm 0.29$ & $11.16 \pm 0.30$ & 0.75 \\
\hline Estrus on D0, \% (n/n) & $\begin{array}{l}53.4 \\
(171 / 320)\end{array}$ & $\begin{array}{l}16.1 \\
(52 / 323)\end{array}$ & $<0.001$ & $\begin{array}{l}31.3 \\
(31 / 99)\end{array}$ & $\begin{array}{l}3.2 \\
(3 / 94)\end{array}$ & $<0.001$ \\
\hline $\mathrm{CL}$ area $\mathrm{D} 4\left(\mathrm{~cm}^{2}\right)$ & $1.31 \pm 0.13$ & $1.22 \pm 0.13$ & 0.006 & $1.07 \pm 0.06$ & $0.95 \pm 0.07$ & 0.13 \\
\hline Ovulation, \% (n/n $)^{\mathrm{a}}$ & $\begin{array}{l}87.2 \\
(279 / 320)\end{array}$ & $\begin{array}{l}84.3 \\
(274 / 323)\end{array}$ & 0.38 & $\begin{array}{l}85.7 \\
(42 / 49)\end{array}$ & $\begin{array}{l}82.2 \\
(37 / 45)\end{array}$ & 0.59 \\
\hline Double ovulation, \% (n/n) & $\begin{array}{l}2.7 \\
(8 / 279)\end{array}$ & $\begin{array}{l}1.4 \\
(4 / 274)\end{array}$ & 0.27 & $\begin{array}{l}2.2 \\
(1 / 46)\end{array}$ & $\begin{array}{l}5.3 \\
(2 / 38)\end{array}$ & 0.46 \\
\hline
\end{tabular}

Abbreviations: FD on D0 = diameter of the largest ovarian follicle at TAI.

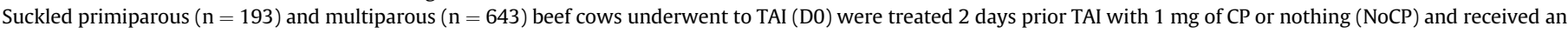

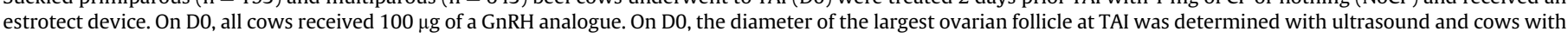

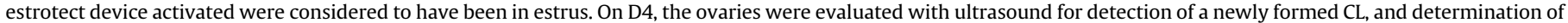
its maximum area. Dataset of primiparous and multiparous cows were analyzed separately.

a On D4, the ultrasound exam was performed only in 94 out of 193 primiparous cows due to operational constraints. 


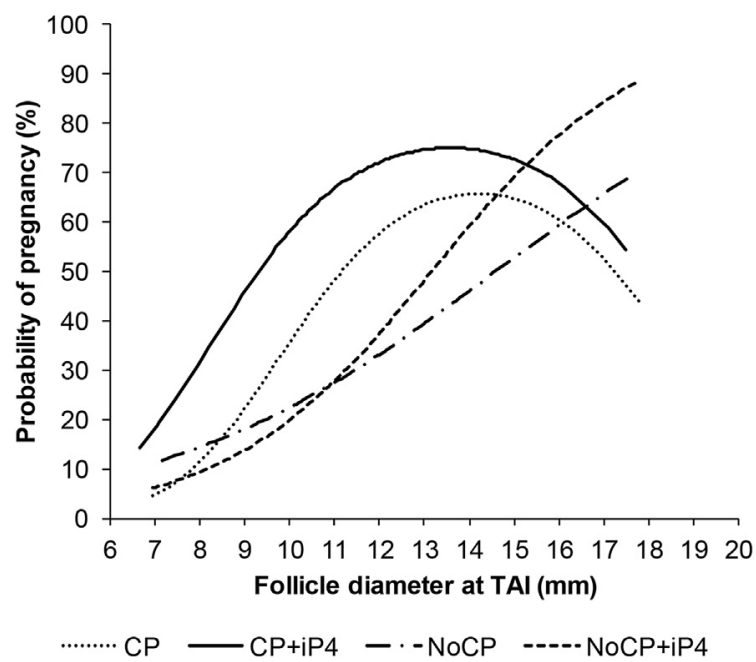

Fig. 1. Relationships between follicle diameter at TAI (D0) and probability of pregnancy of suckled multiparous beef cows $(n=561)$ synchronized with E2/P4 based protocol and assigned to receive nothing or $1 \mathrm{mg}$ of $\mathrm{CP}$ on $\mathrm{D}-2$ and placebo or $150 \mathrm{mg}$ of iP4 on D4 on a 2 by 2 factorial arrangement of treatments. The effect of treatments on probability of pregnancy varied according to follicle diameter $(P=0.04)$. The regression equations were as follows: $\mathbf{C P}=\exp \left(-0.07 \mathrm{x}^{2}+1.99 \mathrm{x}-13.49\right) / 1+\exp$ $\left(-0.07 \mathrm{x}^{2}+1.99 \mathrm{x}-13.49\right) ; \mathbf{C P}+\mathbf{i P 4}=\exp \left(-0.06 \mathrm{x}^{2}+1.63 \mathrm{x}-9.97\right) / 1+\exp$ $\left(-0.06 \mathrm{x}^{2}+1.63 \mathrm{x}-9.97\right) ; \quad$ NoCP $=\exp (0.27 \mathrm{x}-3.94) / 1+\exp (0.27 \mathrm{x}-3.94)$; NoCP $+\mathbf{i P 4}=\exp (0.44 \mathrm{x}-5.79) / 1+\exp (0.44 \mathrm{x}-5.79)$

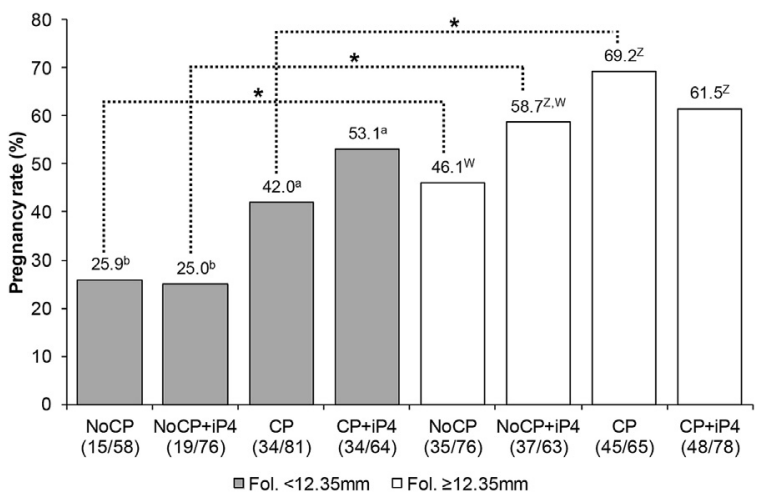

Fig. 2. Effect of classes of follicle diameter at TAI (D0) on pregnancy rates of suckled multiparous beef cows $(\mathrm{n}=561)$ synchronized with E2/P4 based protocol and assigned to receive nothing or $1 \mathrm{mg}$ of CP on D-2 and placebo or $150 \mathrm{mg}$ of iP4 on D4 on a 2 by 2 factorial arrangement of treatments. The effect of treatments on pregnancy rates varied according to follicle diameter $(P=0.06)$. .Significant difference $(P<0.01)$ for comparisons between class of follicle within each group. ${ }^{\mathrm{a}, \mathrm{b}}$ Values without a common superscript differed $(\mathrm{P} \leq 0.05)$ for comparisons performed within class of follicles $<12.35 \mathrm{~mm}$. ${ }^{\mathrm{Z}, \mathrm{W}}$ Values without a common superscript differed $(\mathrm{P} \leq 0.05)$ for comparisons performed within class of follicles $\geq 12.35 \mathrm{~mm}$.

classes of follicles (i.e. $<12.35$ and $\geq 12.35 \mathrm{~mm}$ ), demonstrated that except for the $\mathrm{CP}+\mathrm{iP} 4$ group, every other group presented a smaller pregnancy rate in the class of follicles $<12.35 \mathrm{~mm}$. This indicated that the positive effect of iP4 supplementation for $\mathrm{CP}$ treated cows occurred for cows with smaller follicles $(<12.35 \mathrm{~mm})$.

Contrary to the follicle analysis, the interaction between the covariate CL size and the variables $\mathrm{CP}$ and $\mathrm{PP} 4$ on conception rate was not significant $(P=0.79)$. Regardless of treatment, the conception rate was affected by $C L$ size $(P=0.007$; Fig. 3$)$. Curiously, the equation that better explained the relationship between the covariate CL size and pregnancy rate was of a cubic order. When CLs were categorized according to the median $\left(1.17 \mathrm{~cm}^{2}\right)$ in the classes $<1.17$ and $\geq 1.17 \mathrm{~cm}^{2}$, again, independent of treatment an effect of $\mathrm{CL}$ size was found $(\mathrm{P}=0.002)$. The pregnancy rate of cows with

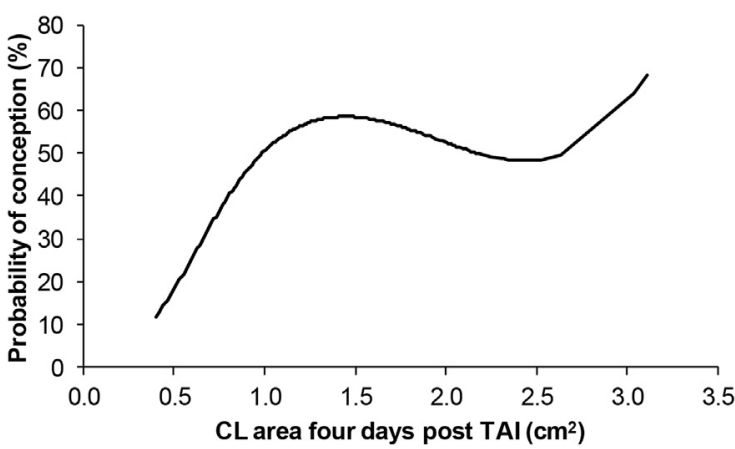

Fig. 3. Relationship between CL area four days post TAI (D0) and the probability of pregnancy of suckled multiparous beef cows $(n=553)$ synchronized with E2/P4 based protocol and assigned to receive nothing or $1 \mathrm{mg}$ of $\mathrm{CP}$ on $\mathrm{D}-2$ and placebo or $150 \mathrm{mg}$ of iP4 on D4 on a 2 by 2 factorial arrangement of treatments. Independent of treatments, the $C L$ area affected $(P=0.007)$ the probability of pregnancy in a cubic order $\left[\exp \left(0.85 \mathrm{x}^{3}-4.95 \mathrm{x}^{2}+8.98 \mathrm{x}-4.86\right) / 1+\exp \left(0.85 \mathrm{x}^{3}-4.95 \mathrm{x}^{2}+8.98 \mathrm{x}-4.86\right)\right]$.

$\mathrm{CL} \geq 1.17 \mathrm{~cm}^{2}$ was greater than those with $\mathrm{CL}<1.17 \mathrm{~cm}$ (57.3\% [160/ 279] vs. $41.7 \%$ [115/276]), which reflects the effects observed in Fig. 3 more clearly.

In addition, at the start of the estrus synchronization protocol $45.4 \%$ [292/643] of multiparous and 8.8\% [17/193] of primiparous cows presented $\mathrm{CL}$, however, the presence or absence of a CL did not affect $(\mathrm{P}>0.10) \mathrm{P} / \mathrm{AI}$.

Interactions between $\mathrm{CP}$ addition prior to TAI and iP4 supplementation at initial diestrus on luteal function and lifespan of suckled beef cows.

In the absence of CP supplementation, iP4 injection on day 4 caused the greatest proportion of early luteolysis (26 and 20\% for structural and functional luteolysis, respectively, for the NoCP + iP4 group; Table 3 ). The addition of $\mathrm{CP}$ prior to TAI prevented the incidence of early luteolysis triggered by iP4 supplementation on day $4(\mathrm{P}<0.05)$. Indeed, $\mathrm{CP}+\mathrm{iP} 4$ treatment resulted in a proportion of cows showing early luteolysis similar to that of groups that did not receive iP4 supplementation.

For cows with a functional CL on day 15 , i.e. no structural or functional luteolysis detected, no effect of iP4 supplementation was observed on CL area or blood flow (Table 3). However, a CP by iP4 interaction approaching significance $(P=0.08)$ indicated that the NoCP group presented a lower $(\mathrm{P}<0.05)$ serum $\mathrm{P} 4$ concentration than the CP group (Table 3$)$. In addition, cows showing estrus had greater serum P4 concentrations $(6.77 \pm 0.43$ vs. NoEstrus: $5.38 \pm 0.24 \mathrm{ng} / \mathrm{mL} ; \mathrm{P}=0.006)$.

\section{Discussion}

The main motivation of the present study was to verify whether the combined supplementation of $\mathrm{CP}$ and iP4 would increase P/AI in suckled beef cows. Expectation was that supplementation of $\mathrm{CP}$ at the beginning of proestrus (day of P4-releasing device removal) in cows supplemented with long-acting P4 at early diestrus would prevent the incidence of iP4-induced early luteolysis. In general, we found that CP treatment: 1) improved the incidence of estrus; 2) increased size of CL at early diestrus; 3 ) increased P4 concentrations at late diestrus; 4) prevented iP4-induced early onset of luteolysis and 5) improved fertility of both multiparous and primiparous beef cattle submitted to TAI, independent of iP4. The fact that early luteolysis was suppressed but P/AI was not further increased after combined CP and iP4 supplementation was intriguing. Further examination of the data after partitioning cows according to size of the preovulatory follicle revealed that the fertility response to $\mathrm{CP}$ and iP4 is complex. Complexity is probably 
Table 3

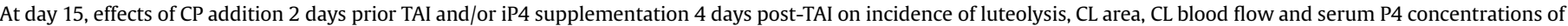
suckled beef cows.

\begin{tabular}{|c|c|c|c|c|c|c|c|}
\hline \multirow[t]{2}{*}{ Variables on D15 } & \multicolumn{2}{|l|}{$\mathrm{CP}$} & \multicolumn{2}{|l|}{ NoCP } & \multicolumn{3}{|c|}{ P value } \\
\hline & NoiP4 & iP4 & NoiP4 & iP4 & $\mathrm{CP}$ & iP4 & $\mathrm{CP}^{*} \mathrm{iP} 4$ \\
\hline Structural lut., \% (n/n) ${ }^{1}$ & $\begin{array}{l}6.4^{\mathrm{b}} \\
(3 / 47)\end{array}$ & $\begin{array}{l}8.3^{\mathrm{b}} \\
(4 / 48)\end{array}$ & $\begin{array}{l}8.0^{\mathrm{b}} \\
(4 / 50)\end{array}$ & $\begin{array}{l}26.0^{\mathrm{a}} \\
(13 / 50)\end{array}$ & . & . & . \\
\hline Functional lut., \% $(\mathrm{n} / \mathrm{n})^{2}$ & $\begin{array}{l}2.1^{\mathrm{b}} \\
(1 / 47)\end{array}$ & $\begin{array}{l}4.2^{\mathrm{b}} \\
(2 / 48)\end{array}$ & $\begin{array}{l}8.0^{\mathrm{a}, \mathrm{b}, \mathrm{Y}} \\
(4 / 50)\end{array}$ & $\begin{array}{l}20.0^{a, X} \\
(10 / 50)\end{array}$ & . & . & . \\
\hline $\mathrm{CL}$ area $\left(\mathrm{cm}^{2}\right)$ & $2.80 \pm 0.08$ & $2.67 \pm 0.08$ & $2.65 \pm 0.08$ & $2.67 \pm 0.09$ & 0.34 & 0.59 & 0.29 \\
\hline CL blood flow, $\%^{3}$ & $44.8 \pm 0.02$ & $43.8 \pm 0.02$ & $44.1 \pm 0.02$ & $44.1 \pm 0.02$ & . & . & . \\
\hline P4 conc. $(\mathrm{ng} / \mathrm{mL})^{4}$ & $6.14 \pm 0.35^{\mathrm{a}}$ & $5.84 \pm 0.35^{\mathrm{a}, \mathrm{b}, \mathrm{X}}$ & $4.95 \pm 0.35^{\mathrm{b}, \mathrm{Y}}$ & $5.84 \pm 0.39^{\mathrm{a}, \mathrm{b}, \mathrm{X}}$ & 0.11 & 0.37 & 0.08 \\
\hline
\end{tabular}

Abbreviations: Structural lut. = structural luteolysis; Functional luteolysis = functional luteolysis; P4 conc. = concentrations of P4

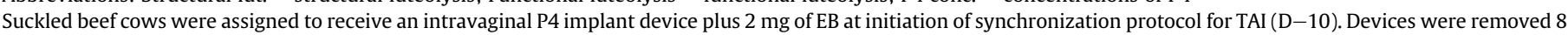

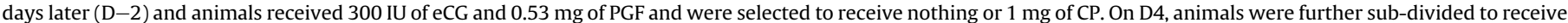

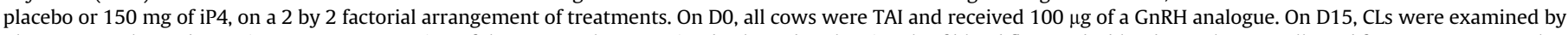

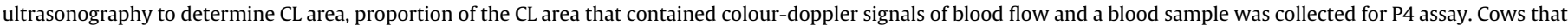
had undergone structural or functional luteolysis were removed from the analysis of CL area, CL blood flow and P4 concentrations.

${ }^{1}$ Structural luteolysis: $\mathrm{CL}$ area $<2.0 \mathrm{~cm}^{2}$ and blood flow rate $\leq 25 \%$.

${ }^{2}$ Functional luteolysis: concentration of $\mathrm{P} 4<1.0 \mathrm{ng} / \mathrm{mL}$. The analyses were performed using Chi-Square test;

${ }^{3}$ Analyzed by Kruskal Wallis test of SAS. The sum of scores were $3928.50,3744.0,3800.50$ and $3233.0 \mathrm{for}$ the $\mathrm{CP}, \mathrm{CP}+\mathrm{iP} 4, \mathrm{NoCP}$ and NoCP $+\mathrm{iP4}$ respectively $(\mathrm{P}=0.93)$;

a,b Values without a common superscript differed between treatments $(\mathrm{P} \leq 0.05)$.

${ }^{X, Y}$ Values without a common superscript tended to differ $(0.05>\mathrm{P} \leq 0.10)$.

due to the isolated and combined effects of CP and iP4 on the preovulatory follicle, the subsequent $\mathrm{CL}$, the reproductive tract and the embryo/conceptus functions.

The CP supplementation prevented the incidence of iP4stimulated early luteolysis. Shortened luteal lifespan in P4supplemented cows $[24,28,40]$ is one explanation for the historically inconsistent fertility results obtained in response to supplementation of P4 at early diestrus. Here, we successfully demonstrated that an injection of CP $48 \mathrm{~h}$ before TAI suppressed the increased incidence of early luteolysis associated with P4 supplementation. Early luteal regression has two main explanations: advanced release of PGF2 $\alpha$ pulses from the endometrium, leading to regression, and luteal insufficiency or sub-functionality. Regarding the endometrium, although we did not evaluate the molecular mechanisms underlying this response, we propose that the $\mathrm{CP}$ effect might be a consequence of the supplemental preovulatory E2 stimulating an increase in the expression of endometrial ESR $\alpha$ and PGR [41,42] at estrus. We rationalized that perhaps a greater starting abundance of PGR would take longer to become down-regulated during early diestrus, and this might counteract the acceleration of PGR loss from the uterine epithelia caused by supplemental P4 [37]. In such scenario, timing of onset of the luteolytic cascade could be reset to that expected on a normal estrous cycle, which would provide enough time for anti-luteolytic signalling from the conceptus [38,39]. This preposition needs specific experimental testing.

Regarding a CP effect on luteal function, we observed that P4 concentration on day 15 of the CP group was $19 \%$ greater than NoCP group, and this was consistent with a $13 \%$ greater CL volume on day 4. Interestingly, increases in $\mathrm{CL}$ growth and function occurred despite the fact that pre-ovulatory follicle sizes were similar among groups. These responses could be related to the longer duration of the LH surge stimulated by CP in comparison to the surge stimulated by the GnRH injection alone. The LH remains elevated up to $16.5 \mathrm{~h}$ after CP-stimulation [46] instead of 6h when a GnRH analogue is injected [50]. Indeed, variations in the magnitude of the LH surge around the time of ovulation were reported to be important for early luteal function [51,52]. In this regard, a possible cause of early luteolysis onset caused by P4 supplementation is because of failures on CL development due to inadequate luteotrophic support $[28,53]$. Administration of human [53] or equine [28] chorionic gonadotrophin concurrent with P4 supplementation prevented early onset of luteolysis in cows. Thus, we infer that CLs from CP-group may be more resilient to the LH pulse frequency inhibition caused by supplemental P4. The possible association between the LH-release dynamics during proestrus and the incidence of short luteal lifespan warrants further investigation.

In the present paper, lack of a main effect of iP4 supplementation and lack of an effect of the interaction CP by iP4 on P/AI and conception rate led to the conclusion that iP4 did not affect fertility. However, a closer look at the data, after stratification by size of the pre-ovulatory follicle, allowed the identification of sub-populations of cows responsive to supplemental P4. Specifically, when follicles were $\geq 12.35 \mathrm{~mm}$, pregnancy rates increased from 46.1 to $58.7 \%$ after administration of iP4 to cows not treated with CP. Furthermore, when follicles were $<12.35 \mathrm{~mm}$, pregnancy rates increased from 42.0 to $53.1 \%$ after administration of iP4 to cows treated with CP (Fig. 2). Thus, in a scenario of presumed low E2 exposure during proestrus, for example in the presence of smaller pre-ovulatory follicles, (Fig. 1), the CP treatment favoured the iP4 supplementation fertility response (i.e. $\mathrm{CP}+\mathrm{iP} 4$ group); in contrast, $\mathrm{CP}$ reduced iP4 benefits when concentrations of E2 were already elevated during proestrus, such as in the presence of a larger follicle. Furthermore, when the pre-ovulatory E2 milieu was generated only by size of follicle (i.e., NoCP groups), the response to iP4 stimulus was verified only for cows with larger follicles. In support of this observation, Madsen et al. [43] demonstrated that lack of E2 exposure during proestrus period impaired the capability of ovariectomized beef cows treated with $\mathrm{P} 4$ to sustain a pregnancy. The authors verified that previous E2 exposure during the proestrus period was required to sustain embryonic growth and or/ placental attachment. Moreover, Davoodi et al. [15] observed that at similar P4 concentrations during diestrus, beef cows that showed estrus at TAI presented longer conceptuses compared to those that did not come in estrus. Collectively, consistent with previous reports, we show here that P4 supplementation may exert embryotrophic [22], luteolytic $[24,40]$ or no effect on the probability of conception of an individual cow. Furthermore, such effects are modulated by exposure to follicular, endogenous and exogenous estradiol. The interacting effects of E2 and P4 coordinate shifts in sub-populations of cows between pregnant and non-pregnant, to yield the overall pregnancy rate. This phenomenon is well illustrated on Fig. 1.

Interpretation of this complex scenario may help us to 
understand why, contrary to our initial hypothesis, the suppression of short luteal lifespan by CP (Table 3 ) did not improve the proportion of pregnant cows after iP4 supplementation (Table 1 and Fig. 2). For example, the $18 \%$ increase in the incidence of early luteolysis in the NoCP $+\mathrm{iP} 4$ vs. the NoCP group (Table 3 ) did not impair P/AI (Table 1). Indeed, numerically, the P/AI of NoCP + iP4 group (37.1\%) was even greater than NoCP (32.9\%). However, magnitude of iP4 effects were clearly affected by size of the preovulatory follicle. For example, the iP4 benefits for NoCP treated cows with follicles $\geq 12.35 \mathrm{~mm}$ (12.6\% increase in pregnancy rate; Fig. 2) probably counterbalanced the overall ip4-luteolytic effect. The numerical improvement on $\mathrm{P} / \mathrm{AI}$ indicates that $\mathrm{P} 4$ benefits in cows with follicles $\geq 12.35 \mathrm{~mm}$ compensated partially the fertility limitations, associated with sub-maximal exposure to preovulatory E2 and incidence of early luteolysis. In fact, the pregnancy rates of NoCP + iP4 group (58.7\%) was intermediary between groups NoCP (46.1\%) and CP (69.2\%), Fig. 2. For the CP treated cows, the absence of iP4-induced early luteolysis (Table 3 ) associated to iP4 fertility benefits (11.1\% increase in pregnancy rate; Fig. 2) for cows with follicles $<12.35 \mathrm{~mm}$ did not result in gains in the P/AI (Table 1). This was probably due to the reduced benefits of iP4 when follicles were larger (Fig. 1). In this regard, for animals treated with $\mathrm{CP}$, the numerical decrease $(7.7 \%)$ in the pregnancy rate of cows with follicles $\geq 12.35 \mathrm{~mm}$ treated with iP4 (Fig. 2) suggest that the positive effect of iP4 was abrogated in these sub-populations of cows, but this was not because of iP4-induced early luteolysis. Thus, our findings indicated that success of iP4 supplementation in TAI programs depends on the endocrine profiles resulting from the TAI programs. This implies that an iP4 treatment designed specifically to certain populations of cows within TAI programs should be considered in future investigations.

The present results involving $\mathrm{CP}$ supplementation and size of follicles at TAI confirm, respectively, the strong positive association between (i) the circulating estradiol concentrations during proestrus and fertility $[5,8,10,44]$ and (ii) the follicle diameter at TAI and fertility $[1-3,6]$.

In conclusion, the present data highlighted the complex interplay among endogenous and exogenous estradiol and supplementary P4 on beef cow fertility. The association of supplemental E2 and P4 can increase pregnancy rates in sub-populations of cows with smaller follicles at TAI and this may be partially due to a decrease in the incidence of early onset of luteolysis. The precise mechanisms by which $\mathrm{CP}$ induces these effects need to be determined. From a practical standpoint, exogenous E2 addition at the beginning of proestrus reduces the occurrence of early luteolysis in P4-supplemented cows at early diestrus and, strategies associating E2 and P4 supplementation have a potential positive impact on the reproductive performance of suckled beef cows.

\section{Acknowledgments}

This work was supported by LFEM (Project \# 225) and FAPESP (2011/03226-4). The authors are very thankful to the Marcos Rocha, Valdo Batista and Graziela Rocha Batista for allowed the use of facilities and animals from the farms, to the Ouro Fino Saúde Animal for donation of hormones and to the CAPES (33002010047P6) and FAPESP (2015/26215-9) for a scholarship granted to the first author.

\section{References}

[1] Sá Filho MF, Crespilho AM, Santos JEP, Perry GA, Baruselli PS. Ovarian follicle diameter at timed insemination and estrous response influence likelihood of ovulation and pregnancy after estrous synchronization with progesterone or progestin-based protocols in suckled Bos indicus cows. Anim Reprod Sci 2010;120:23-30. http://dx.doi.org/10.1016/j.anireprosci.2010.03.007.

[2] Perry GA, Smith MF, Roberts AJ, MacNeil MD, Geary TW. Relationship between size of the ovulatory follicle and pregnancy success in beef heifers. J Anim Sci 2007;85:684-9. http://dx.doi.org/10.2527/jas.2006-519.

[3] Martins T, Peres RFG, Rodrigues ADP, Pohler KG, Pereira MHC, Day ML, et al. Effect of progesterone concentrations, follicle diameter, timing of artificial insemination, and ovulatory stimulus on pregnancy rate to synchronized artificial insemination in postpubertal Nellore heifers. Theriogenology 2014;81:446-53. http://dx.doi.org/10.1016/j.theriogenology.2013.10.020.

[4] Perry GA, Smith MF, Lucy MC, Green JA, Parks TE, MacNeil MD, et al. Relationship between follicle size at insemination and pregnancy success. Proc Natl Acad Sci U. S. A 2005;102:5268-73. http://dx.doi.org/10.1073/ pnas.0501700102.

[5] Jinks EM, Smith MF, Atkins JA, Pohler KG, Perry GA, MacNeil MD, et al. Preovulatory estradiol and the establishment and maintenance of pregnancy in suckled beef cows. J Anim Sci 2013;91:1176-85. http://dx.doi.org/10.2527/ jas.2012-5611.

[6] Peres RFG, Júnior IC, Filho OGS, Nogueira GDP, Vasconcelos JLM. Strategies to improve fertility in Bos indicus postpubertal heifers and nonlactating cows submitted to fixed-time artificial insemination. Theriogenology 2009;72: 681-9. http://dx.doi.org/10.1016/j.theriogenology.2009.04.026.

[7] Dias CC, Wechsler FS, Day ML, Vasconcelos JLM. Progesterone concentrations, exogenous equine chorionic gonadotropin, and timing of prostaglandin F2 $\alpha$ treatment affect fertility in postpuberal Nelore heifers. Theriogenology 2009;72:378-85. http://dx.doi.org/10.1016/j.theriogenology.2009.03.006.

[8] Bridges GA, Mussard ML, Burke CR, Day ML. Influence of the length of proestrus on fertility and endocrine function in female cattle. Anim Reprod Sci 2010;117:208-15. http://dx.doi.org/10.1016/j.anireprosci.2009.05.002.

[9] Bridges GA, Helser LA, Grum DE, Mussard ML, Gasser CL, Day ML. Decreasing the interval between GnRH and PGF2 $\alpha$ from 7 to 5 days and lengthening proestrus increases timed-AI pregnancy rates in beef cows. Theriogenology 2008;69:843-51. http://dx.doi.org/10.1016/j.theriogenology.2007.12.011.

[10] Sá Filho MF, Santos JEP, Ferreira RM, Sales JNS, Baruselli PS. Importance of estrus on pregnancy per insemination in suckled Bos indicus cows submitted to estradiol/progesterone-based timed insemination protocols. Theriogenology 2011;76:455-63. http://dx.doi.org/10.1016 j.theriogenology.2011.02.022.

[11] Pereira MHC, Rodrigues ADP, Martins T, Oliveira WVC, Silveira PSA Wiltbank MC, et al. Timed artificial insemination programs during the summer in lactating dairy cows: comparison of the 5-d Cosynch protocol with an estrogen/progesterone-based protocol. J Dairy Sci 2013;96:6904-14. http:// dx.doi.org/10.3168/jds.2012-6260.

[12] Perry GA, Perry BL. Effects of standing estrus and supplemental estradiol on changes in uterine $\mathrm{pH}$ during a fixed-time artificial insemination protocol. J Anim Sci 2008;86:2928-35. http://dx.doi.org/10.2527/jas.2008-1181.

[13] Mann GE, Lamming GE. The role of sub-optimal preovulatory oestradiol secretion in the aetiology of premature luteolysis during the short oestrous cycle in the cow. Anim Reprod Sci 2000;64:171-80. http://dx.doi.org/ 10.1016/S0378-4320(00)00205-0.

[14] Kieborz-Loos KR, Garverick HA, Keisler DH, Hamilton SA, Salfen BE Youngquist RS, et al. Oxytocin-induced secretion of prostaglandin F2alpha in postpartum beef cows: effects of progesterone and estradiol-17beta treatment. J Anim Sci 2003;81:1830-6.

[15] Davoodi S, Cooke RF, Fernandes ACC, Cappellozza BI, Vasconcelos JLM, Cerri RLA. Expression of estrus modifies the gene expression profile in reproductive tissues on day 19 of gestation in beef cows. Theriogenology 2015;85:645-55. http://dx.doi.org/10.1016/j.theriogenology.2015.10.002.

[16] Mesquita FS, Ramos RS, Pugliesi G, Andrade SCS, Van Hoeck V, Langbeen A, et al. The receptive endometrial transcriptomic signature indicates an earlier shift from proliferation to metabolism at early diestrus in the cow. Biol Reprod 2015;93:1-12. http://dx.doi.org/10.1095/biolreprod.115.129031.

[17] Frade MC, Frade C, Cordeiro MB, Sá Filho MF, Mesquita FS, Nogueira GDP, et al. Manifestation of estrous behavior and subsequent progesterone concentration at timed-embryo transfer in cattle are positively associated with pregnancy success of recipients. Anim Reprod Sci 2014;151:85-90. http:// dx.doi.org/10.1016/j.anireprosci.2014.09.005.

[18] Mann GE, Lamming GE. Relationship between maternal endocrine environment, early embryo development and inhibition of the luteolytic mechanism in cows. Reproduction 2001;121:175-80. http://dx.doi.org/10.1530/reprod/ 121.1.175.

[19] Spencer TE, Forde N, Lonergan P. The role of progesterone and conceptusderived factors in uterine biology during early pregnancy in ruminants. J Dairy Sci 2015;99:1-10. http://dx.doi.org/10.3168/jds.2015-10070.

[20] Spencer TE, Johnson GA, Bazer FW, Burghardt RC. Implantation mechanisms: insights from the sheep. Reproduction 2004;128:657-68. http://dx.doi.org/ 10.1530/rep.1.00398.

[21] Garrett JE, Geisert RD, Zavy MT, Gries LK, Wettemann RP, Buchanan DS. Effect of exogenous progesterone on prostaglandin F2 $\alpha$ release and the interestrous interval in the bovine. Prostaglandins 1988;36:85-96.

[22] Carter F, Forde N, Duffy P, Wade M, Fair T, Crowe MA, et al. Effect of increasing progesterone concentration from Day 3 of pregnancy on subsequent embryo survival and development in beef heifers. Reprod Fertil Dev 2008;20:368-75. http://dx.doi.org/10.1071/RD07204.

[23] Clemente M, De La Fuente J, Fair T, Al Naib A, Gutierrez-Adan A, Roche JF, et al. Progesterone and conceptus elongation in cattle: a direct effect on the embryo or an indirect effect via the endometrium? Reproduction 2009;138:507-17. http://dx.doi.org/10.1530/REP-09-0152. 
[24] O'Hara L, Forde N, Carter F, Rizos D, Maillo V, Ealy AD, et al. Paradoxical effect of supplementary progesterone between day 3 and day 7 on corpus luteum function and conceptus development in cattle. Reprod Fertil Dev 2014;26: 328-36. http://dx.doi.org/10.1071/RD12370.

[25] Forde N, Carter F, Fair T, Crowe MA, Evans ACO, Spencer TE, et al. Progesterone-regulated changes in endometrial gene expression contribute to advanced conceptus development in cattle. Biol Reprod 2009;81:784-94. http://dx.doi.org/10.1095/biolreprod.108.074336.

[26] Mann GE, Lamming GE. The influence of progesterone during early pregnancy in cattle. Reprod Domest Anim 1999;34:269-74. http://dx.doi.org/10.1111/ j.1439-0531.1999.tb01250.x.

[27] Yan L, Robinson R, Shi Z, Mann G. Efficacy of progesterone supplementation during early pregnancy in cows: a meta-analysis. Theriogenology 2016;85: 1390-8. http://dx.doi.org/10.1016/j.theriogenology.2015.12.027.

[28] O'Hara L, Forde N, Duffy P, Randi F, Kelly AK, Valenza A, et al. Effect of combined exogenous progesterone with luteotrophic support via equine chorionic gonadotrophin (eCG) on corpus luteum development, circulating progesterone concentrations and embryo development in cattle. Reprod Fertil Dev 2014:269-77. http://dx.doi.org/10.1071/RD14019.

[29] Monteiro PLJ, Nascimento AB, Pontes GCS, Fernandes GO, Melo LF, Wiltbank MC, et al. Progesterone supplementation after ovulation: effects on corpus luteum function and on fertility of dairy cows subjected to AI or ET. Theriogenology 2015;84:1215-24. http://dx.doi.org/10.1016 j.theriogenology.2015.06.023.

[30] Stevenson JS, Mee MO. Pregnancy rates of holstein cows after postinsemination treatment with a progesterone-releasing intravaginal device. J Dairy Sci 1991;74:3849-56. http://dx.doi.org/10.3168/jds.S0022-0302(91) 78577-9.

[31] Monteiro PLJ, Ribeiro ES, Maciel RP, Dias ALG, Solé E, Lima FS, et al. Effects of supplemental progesterone after artificial insemination on expression of interferon-stimulated genes and fertility in dairy cows. J Dairy Sci 2014;97: 4907-21. http://dx.doi.org/10.3168/jds.2013-7802.

[32] Parr MH, Crowe MA, Lonergan P, Evans ACO, Rizos D, Diskin MG. Effect of exogenous progesterone supplementation in the early luteal phase postinsemination on pregnancy per artificial insemination in Holstein-Friesian cows. Anim Reprod Sci 2014;150:7-14. http://dx.doi.org/10.1016/ j.anireprosci.2014.08.008.

[33] Van Cleeff J, Macmillan KL, Drost M, Lucy MC, Thatcher WW. Effects of administering progesterone at selected intervals after insemination of synchronized on pregnancy rates and resynchronization of returns to service. Theriogenology 1996;46:1117-30. http://dx.doi.org/10.1016/S0093691X(96)00284-1.

[34] Pugliesi G, Santos FB, Lopes E, Nogueira É, Maio JRG, Binelli M. Improved fertility in suckled beef cows ovulating large follicles or supplemented with long-acting progesterone after timed-AI. Theriogenology 2016;85:1239-48. http://dx.doi.org/10.1016/j.theriogenology.2015.12.006.

[35] Robinson NA, Leslie KE, Walton JS. Effect of treatment with progesterone on pregnancy rate and plasma concentrations of progesterone in holstein cows. J Dairy Sci 1989;72:202-7. http://dx.doi.org/10.3168/jds.S0022-0302(89) 79098-6.

[36] Johnson KR, Barth EJ, Science A, Soc SREA. Effect of 17 $\alpha$-hydroxyprogesterone 17-n-caproate on the reproductive performance of cattle. Ann N. Y Acad Sci 1958;71:577-9.

[37] Okumu LA, Forde N, Fahey AG, Fitzpatrick E, Roche JF, Crowe MA, et al. The effect of elevated progesterone and pregnancy status on mRNA expression and localisation of progesterone and oestrogen receptors in the bovine uterus. Reproduction 2010;140:143-53. http://dx.doi.org/10.1530/REP-10-0113.

[38] Spencer T. Conceptus signals for establishment and maintenance of pregnancy. Anim Reprod Sci 2004;15:1-15. http://dx.doi.org/10.1016/S0378-
4320(04)00070-3.

[39] Spencer TE, Johnson GA, Bazer FW, Burghardt RC, Palmarini M. Pregnancy recognition and conceptus implantation in domestic ruminants: roles of progesterone, interferons and endogenous retroviruses. Reprod Fertil Dev 2007;19:65-78. http://dx.doi.org/10.1071/RD06102.

[40] Pugliesi G, Oliveria ML, Scolari SC, Lopes E, Pinaffi FV, Miagawa BT, et al. Corpus luteum development and function after supplementation of longacting progesterone during the early luteal phase in beef cattle. Reprod Domest Anim 2014;49:85-91. http://dx.doi.org/10.1111/rda.12231.

[41] Ing NH, Tornesi MB. Estradiol up-regulates estrogen receptor and progesterone receptor gene expression in specific ovine uterine cells. Biol Reprod 1997; $56: 1205-15$

[42] Robinson RS, Mann GE, Lamming GE, Wathes DC. Expression of oxytocin, oestrogen and progesterone receptors in uterine biopsy samples throughout the oestrous cycle and early pregnancy in cows. Reproduction 2001;122: 965-79.

[43] Madsen CA, Perry GA, Mogck CL, Daly RF, MacNeil MD, Geary TW. Effects of preovulatory estradiol on embryo survival and pregnancy establishment in beef cows. Anim Reprod Sci 2015;158:96-103. http://dx.doi.org/10.1016/ j.anireprosci.2015.05.006.

[44] Pereira MHC, Wiltbank MC, Vasconcelos JLM. Expression of estrus improves fertility and decreases pregnancy losses in lactating dairy cows that receive artificial insemination or embryo transfer. J Dairy Sci 2016;99:2237-47. http://dx.doi.org/10.3168/jds.2015-9903.

[45] Houghton PL, Lemenager RP, Moss GE, Hendrix KS. Prediction of postpartum beef cow body composition using weight to height ratio and visual body condition score. J Anim Sci 1990;68:1428-37.

[46] Sales JNS, Carvalho JBP, Crepaldi GA, Cipriano RS, Jacomini JO, Maio JRG, et al. Effects of two estradiol esters (benzoate and cypionate) on the induction of synchronized ovulations in Bos indicus cows submitted to a timed artificial insemination protocol. Theriogenology 2012;78:510-6. http://dx.doi.org/ 10.1016/j.theriogenology.2012.02.031.

[47] Colazo MG, Kastelic JP, Mapletoft RJ. Effects of estradiol cypionate (ECP) on ovarian follicular dynamics, synchrony of ovulation, and fertility in CIDRbased, fixed-time AI programs in beef heifers. Theriogenology 2003;60: 855-65. http://dx.doi.org/10.1016/S0093-691X(03)00091-8.

[48] Pugliesi G, Beg MA, Carvalho GR, Ginther OJ. Induction of PGFM pulses and luteolysis by sequential estradiol-17 $\beta$ treatments in heifers. Theriogenology 2012;77:492-506. http://dx.doi.org/10.1016/j.theriogenology.2011.08.020.

[49] Pugliesi G, Miagawa BT, Paiva YN, Franca MR, Silva LA, Binelli M. Conceptusinduced changes in the gene expression of blood immune cells and the ultrasound-accessed luteal function in beef cattle: how early can we detect pregnancy? Biol Reprod 2014;91:1-12. http://dx.doi.org/10.1095/ biolreprod.114.121525.

[50] Picard-Hagen N, Lhermie G, Florentin S, Merle D, Frein P, Gayrard V. Effect of gonadorelin, lecirelin, and buserelin on LH surge, ovulation, and progesterone in cattle. Theriogenology 2014;84:177-83. http://dx.doi.org/10.1016/ j.theriogenology.2015.03.004.

[51] Fields SD, Perry BL, Perry GA. Effects of GnRH treatment on initiation of pulses of LH, LH release, and subsequent concentrations of progesterone. Domest Anim Endocrinol 2009:37:189-95 http://dx.doi.org/10.1016 j.domaniend.2009.04.006.

[52] Quintal-Franco JA, Kojima FN, Melvin EJ, Lindsey BR, Zanella E, Fike KE, et al. Corpus luteum development and function in cattle with episodic release of luteinizing hormone pulses inhibited in the follicular and early luteal phases of the estrous cycle. Biol Reprod 1999;61:921-6. http://dx.doi.org/10.1095/ biolreprod61.4.921.

[53] Ginther OJ. Effect of progesterone on length of estrous cycle in cattle. Am J Vet Res 1970;31:493-6. 